\title{
Evaluation of furrow fertigation on nitrogen supply and losses as a function of maize growth stages
}

\author{
Amir Mohseni ${ }^{1}\left[\right.$ Dossein Mirseyed Hosseini ${ }^{1} \cdot$ Fariborz Abbasi $^{2}$
}

Received: 13 September 2020 / Accepted: 21 December 2020 / Published online: 11 January 2021

(C) The Author(s) 2021 OPEN

\begin{abstract}
The purpose of this study was to evaluate the effects of furrow fertigation on nitrate deep leaching, nitrate runoff losses, and plant nitrogen supply in various growth stages of maize (Zea mays L.). Furrow fertigation experiment was conducted in 120 (W1), 100 (W2), 80 (W3), and 60\% (W4) levels of required water (560 mm) and 100 (N1), 80 (N2), 60 (N3), and 0\% (N4) levels of required nitrogen fertilizer $\left(184 \mathrm{~kg} \mathrm{~N} \mathrm{ha}^{-1}\right)$. $\mathrm{N}$-fertilizer was applied in four split applications (before planting, at the seven-leaf, shooting, and flowering). In the farmers' conventional fertilization (FCF) method, $120 \%$ level of required water and $100 \%$ level of the required $\mathrm{N}$-fertilizer were used in two split applications (before planting and at the seven-leaf stage). Results showed that the highest maize aboveground nitrogen content was $3.11 \%$ for FCF treatments at the seven-leaf stage. The maximum nitrogen content in the sensitive flowering stage and the maximum grain yield were also observed in W2N1 treatment with $2.27 \%$ and 12.93 ton ha ${ }^{-1}$, respectively. While, there were no significant differences in aboveground nitrogen content and grain yield between W2N1 and W3N1, W2N2, and W3N2. The highest amounts of nitrate leaching out of the $80-\mathrm{cm}$ soil layer and nitrate runoff losses, were also recorded in FCF treatment, followed by W1N1, W2N1, and W3N1. Based on plant nitrogen content, nitrate losses and maize yield, $80 \%$ levels of the required $\mathrm{N}$-fertilizer and required irrigation water could be recommended as the optimal levels to reduce nitrate losses and improve maize yield.
\end{abstract}

Keywords Furrow fertigation · Maize yield · Nitrate loss · Aboveground nitrogen · Surface runoff

\section{Introduction}

Water and nitrogen are the two key factors in agriculture production. The relationship between nitrogen and water supply for crop production has been proved [1]. N uptake from soil is influenced by higher water supply [2]. The amount of nitrogen supply and uptake by the plant is a function of root and shoot growth stages [3]. The optimal amount of $\mathrm{N}$ uptake induced by $\mathrm{N}$-fertilizer occurs at the sufficient water supply, leading to higher crop production [4]. The excessive application of water and nitrogen in the conventional method which fertilizer is spread on soil surface, are the main cause of nitrate leaching [5]; that can cause the water surface and groundwater contamination [6]. Fertigation methods through reduction of applied fertilizer amount and enhanced fertilizer uptake efficiency reduce fertilizer inputs and consequently mitigate potential environmental contamination [7]. This method increases nutrient uptake through preserving optimal level of nutrients in the plant root zone during the growing period, and enhanced timing of nutrient applications simultaneously declined $\mathrm{N}$ leaching compared to farmers' conventional fertilization where a large portion of the nitrogen is applied before planting [8]. Several

$\triangle$ Amir Mohseni, amir.mohseni65@gmail.com | ${ }^{1}$ Department of Soil Science, College of Agriculture and Natural Resources, University of Tehran, Karaj, Iran. ${ }^{2}$ Agricultural Engineering Research Institute, Agriculture Research, Education and Extension Organization (AREEO), Karaj, Iran. 
studies have been conducted to investigate the effect of fertigation, often in pressurized irrigation and humid and sub-humid regions $[9,10]$, but limited reports have shown the effects of furrow fertigation on nitrate deep leaching, nitrate runoff loss, and plant nitrogen supply in various stages of plant growth. Gheysari et al. [11] concluded that fertigation via sprinkler irrigation decreased nitrate leaching and increased total aboveground biomass. They stated that the reason for this trend due to maintaining an optimal level of water and $\mathrm{N}$-fertilizer in the soil during the growing period of maize. Smika et al. [12] measured nitrate losses during the growing season of three cornfields in northeastern Colorado irrigated with a center pivot system. They stated that average losses over three years ranged from 19 to $60 \mathrm{~kg} \mathrm{~N} \mathrm{ha}^{-1}$, depending on the irrigation and $\mathrm{N}$ management. Antille [13] evaluated the effects of furrow fertigation on cotton yield and reported that the $\mathrm{N}$-fertilizer applied through furrow fertigation increased cotton lint yield by about $136.2 \mathrm{~kg} \mathrm{ha}^{-1}$. However, a study by Hou et al. [14] observed that furrow fertigation led to increased cotton dry matter and nitrogen content, and reduced nitrate losses. In the furrow fertigation, nitrogen uptake, nitrate leaching by surface runoff and deep percolation is associated with the management of irrigation, injection time, duration, and content of injected fertilizer $[15,16]$. Šimůnek et al. [17] stated that the minimum amount of solute was leached from the soil deep for furrow fertigation treatments when fertigation was applied at the end of the irrigation cycle. Considering that furrow irrigation is widely used in arid and semiarid areas, especially in Iran, and the potential for water and fertilizer losses, the overall aim of this study was to optimize fertilizer and water application in this irrigation method. This was achieved by three primary objectives: (1) comparing furrow fertigation and farmers' conventional fertilization method, to assess nitrate losses through surface runoff and deep leaching during the growth stages of maize (2) investigating the response of maize grain yield and vegetative characteristics to different levels of irrigation and rates of applied $\mathrm{N}$-fertilizer during the growth stages of maize (3) and determining the optimal level of $\mathrm{N}$ application and water irrigation.

\section{Materials and methods}

\subsection{Description of experimental field}

The study was conducted on 2 hectares farm at the Agricultural Engineering Research Institute, Karaj, Iran $\left(35^{\circ}\right.$ $\left.5^{\prime} \mathrm{N}, 50^{\circ} 58^{\prime} \mathrm{E}\right)$. Soil samples were collected from the three depths of the soil before planting. Samples were air-dried and passed through a $2 \mathrm{~mm}$ sieve. Soil texture [18], $\mathrm{pH}$ and electrical conductivity (ECe) [19, 20], bulk density [21], and soil organic matter [22] were determined. A pressure plate apparatus was used to determine the water holding capacity at $0.03 \mathrm{MPa}(\mathrm{FC})$ and $1.5 \mathrm{MPa}$ (PWP). Some Physical and chemical properties of the soil are given in Table1.

\subsection{Seedling and fertigation experiments}

The furrow fertigation experiment was conducted in a factorial randomized complete blocks design (RCBD) with four replications. There were four levels of irrigation water [W1:120\% (over-irrigation), W2:100\% (full irrigation), W3:80\% and W4:60\% levels of required irrigation water), four levels of nitrogen fertilizer (N1:100\%, N2:80\%, N3:60\% and $\mathrm{N} 4: 0 \%$ levels of required $\mathrm{N}$-fertilizer), and four growth stages of double-cross maize cultivar 370 (seven-leaf, shooting, flowering, and harvesting stages].

Nitrogen requirement was determined by soil analysis (184 kg N ha ${ }^{-1}$, Urea-46\%N) and applied in four split applications (25\% before planting, $25 \%$ at the seven-leaf stage, $25 \%$ at the shooting stage, and $25 \%$ at the flowering stage), which the first portion (before planting) was applied manually and others by fertigation. According to the previous studies by Abbasi et al. [23, 24], fertilizer injection at the end of the cycle or second half time of irrigation had a more distribution and fewer fertilizer losses. Therefore, in the study, injection time was applied in 20 min remained to cut-off irrigation time. In the fertigation blocks, each block included seven furrows with the $75 \mathrm{~cm}$ furrow spacing (five monitored furrows in the middle and two furrows as the border).

The net irrigation requirement was determined based on Class A-evaporation pan, crop coefficient $(\mathrm{Kc})$, and pan coefficients $(\mathrm{Kp})$ as the full irrigation treatment
Table 1 Selected properties of soil samples

\begin{tabular}{llllllll}
\hline $\begin{array}{l}\text { Organic } \\
\text { matter (\%) }\end{array}$ & ECe $\left(\mathrm{dsm}^{-1}\right)$ & $\mathrm{pH}$ & $\begin{array}{l}\text { Permanent wilt- } \\
\text { ing Point (\%) }\end{array}$ & $\begin{array}{l}\text { Field } \\
\text { capacity } \\
(\%)\end{array}$ & $\begin{array}{l}\text { Bulk density } \\
\left(\mathrm{g} \mathrm{cm}^{-1}\right)\end{array}$ & Depth $(\mathrm{cm})$ & Texture \\
\hline 1.26 & 2.03 & 7.44 & 8.96 & 15.75 & 1.49 & $0-25$ & Loam \\
1.12 & 2.01 & 7.59 & 9.11 & 15.50 & 1.57 & $25-50$ & Loam \\
1.04 & 1.78 & 7.47 & 8.16 & 16.33 & 1.56 & $50-75$ & Loam \\
\hline
\end{tabular}


(W2) [25]. The evaporation data were collected from Class A-evaporation pan at a meteorological observatory located approximately $2 \mathrm{~km}$ away from the farm. Subsequently, furrow inflow and outflow were measured using WSC flumes. Irrigation interval varied between 6 and 10 days during the growing season. Other irrigation treatments (W1, W3, and W4) were applied as much as a fraction of the full irrigation requirement (W2).

In the farmers' conventional fertilization treatment (FCF), the total $\mathrm{N}$-fertilizer requirement (N1: 100\%) was used in two split applications (50\% before planting and $50 \%$ at the seven-leaf stage) by manual distribution, plus the over-irrigation (120\% level of required irrigation water). The Cumulative amount of irrigation water applied for irrigation treatments presented in Table 2.

\subsection{Nitrate runoff loss and plant sampling}

At each growth stage (seven-leaf, shooting, flowering, and harvesting), random samples of the plants were collected from the five monitored furrows in the middle, and then plant grain yield and vegetative characteristics such as plant height, stem diameter, and leaf number were determined. Plant height $(\mathrm{cm})$, plant stem diameter $(\mathrm{cm})$, and leaf number was determined in the field using a ruler from the ground surface to the tip of the plant, the Vernier Caliper, and by counting the number of leaves that have visible collars, respectively $[26,27]$. The plant aboveground (including the leaf, flower, and stem) was dried (at $75^{\circ} \mathrm{C}$ ) for $48 \mathrm{~h}$, weighed, and ground for digestion and plant nitrogen extraction. The total aboveground nitrogen was measured using the Kjeldahl method [28].

Samples of overland water for analysis of nitrate concentration were taken at the end of furrows. Samples were collected every 2-3 min, analyzed for nitrate by using the brucine method [29], and reported as the cumulative nitrate content.

Table 2 Cumulative of used water in different irrigation treatments

\begin{tabular}{ll}
\hline Irrigation water treatments & $\begin{array}{l}\text { Net irriga- } \\
\text { tion depth } \\
(\mathrm{mm})\end{array}$ \\
\hline W1: $120 \%$ & 686 \\
W2: $100 \%$ & 560 \\
W3: $80 \%$ & 494 \\
W4: 60\% & 370 \\
W1 (FCF): 120\% & 716 \\
\hline
\end{tabular}

FCF farmers' conventional fertilization

\subsection{Determination of nitrate deep leaching}

Soil nitrate was measured using the brucine method in soil samples to a depth of $80 \mathrm{~cm}$ at four stages (seven-leaf, shooting, flowering, and harvesting) [29]. For determining the nitrate deep leaching, the mass balance approach was used, based on the following equation [11]:

$N_{\text {Leach }}=N_{\text {fert }}+N_{\text {initial }}+N_{\text {iw }}-N_{\text {Plant }}-N_{\text {sr }}-N_{\text {final }}$

where $\mathrm{N}_{\text {fert }}$ is the nitrate added to the soil through fertilizer, $\mathrm{N}_{\text {initial }}$ is the initial nitrate in the $80 \mathrm{~cm}$ soil depth, $\mathrm{N}_{\text {iw }}$ is the nitrate added to the soil from irrigation water, $\mathrm{N}_{\text {plant }}$ is the nitrogen uptake by the plant, $\mathrm{N}_{s r}$ is the nitrate lost through surface runoff from the end of furrows, and $\mathrm{N}_{\text {final }}$ is the residual nitrate in the $80 \mathrm{~cm}$ soil depth.

\subsection{Statistical analysis}

The analysis of variance (ANOVA) for the maize growth stages and treatment effects, and their interaction on the plant aboveground nitrogen content was performed in the Statistical Analysis System (SAS 9.2). Comparisons of plant nitrogen content, plant yield, and nitrogen losses in different levels of $\mathrm{N}$-fertilizer and irrigation water, and growth stages of maize were also analyzed and compared using LSD tests in the Statistical Analysis System (SAS 9.2) at $P \leq 0.05$.

\section{Result and discussion}

\subsection{Plant nitrogen content}

Analysis of variance (ANOVA) for the plant aboveground nitrogen content at different levels of $\mathrm{N}$-fertilizer and irrigation water levels, and growth stages of maize is presented in Table 3. The results showed that $\mathrm{N}$-fertilizer and irrigation water levels, and maize growth stages, and their interactions had a significant effect on aboveground nitrogen content $(P \leq 0.001)$. Acquisition of water and nitrogen is significantly affected by plant growth stages [30]. Nitrogen content in plant tissues is also driven by $\mathrm{N}$-fertilizer and irrigation water levels, and method of $\mathrm{N}$-fertilizer application. Accordingly, the $\mathrm{N}$-fertilizer and irrigation water are the major inputs for enhancing the efficiency of nitrogen and water use, and reducing water surface and groundwater contamination [31].

A general comparison between maize aboveground nitrogen content in furrow fertigation (FF) and farmers' conventional fertilization (FCF) treatments revealed that FCF treatment had the highest aboveground nitrogen 
Table 3 Analysis of variance for effects of $\mathrm{N}$-fertilizer and irrigation water levels, and maize growth stages on aboveground nitrogen content

\begin{tabular}{llccrr}
\hline Resources changes & $d f$ & Sum square & Mean square & Fvalue & $P$ value \\
\hline FER & 3 & 11.13 & 3.711 & 337.28 & $\leq 0.001$ \\
IRR & 3 & 2.01 & 0.67 & 60.77 & $\leq 0.001$ \\
MGS & 3 & 83.84 & 27.94 & 2539.71 & $\leq 0.001$ \\
FER: IRR & 9 & 1.01 & 0.11 & 10.16 & $\leq 0.001$ \\
FER: MGS & 9 & 4.04 & 0.45 & 40.80 & $\leq 0.001$ \\
IRR: MGS & 9 & 1.99 & 0.22 & 20.10 & $\leq 0.001$ \\
FER: IRR: MGS & 27 & 6.41 & 0.24 & 21.58 & $\leq 0.001$ \\
Coefficient of variation (CV) & 6.23 & & & &
\end{tabular}

FER N-fertilizer levels, IRR irrigation water levels, MGS maize growth stages content at the seven-leaf stage in comparison with $\mathrm{FF}$ treatments (Table 4). The lowest nitrogen content was obtained in W4N4 treatment at the harvesting stage. At the sensitive flowering stage, the maximum aboveground nitrogen was observed in W2N1 with an amount of $2.27 \%$, while there was no significant difference in aboveground nitrogen content at the flowering stage between W2N1 treatment and W3N1, W2N2, and W3N2 treatments. Moreover, $60 \%$ (W4) and $120 \%$ (W1) levels of required irrigation water in all levels of required $\mathrm{N}$-fertilizer had significantly lower nitrogen content compared with other fertigation treatments. The reason for the nitrogen reduction at $120 \%$ level of required irrigation water may be attributed to the higher nitrate losses through deep leaching and surface runoff, and denitrification (because of higher moisture) [32]. In contrast, lower water intake in treatments with
$60 \%$ level of required irrigation water may be responsible for the nitrogen reduction at these treatments. Generally, $\mathrm{N}$-fertilizer application in the early growth stages of the plan increases the $\mathrm{N}$ loss risk from the root zone. Therefore, the nitrogen use efficiency is maximized when fertilizer is applied shortly before the period of most rapid crop $\mathrm{N}$ uptake (flowering stage) [33]. Girma et al. [34] investigated aboveground nitrogen accumulation in deference stages of corn growth. Their results showed that $45 \%$ of the nitrogen requirement of the plant was between eight_leaf and flowering stages. Hocking and Stapper [35] found that the most important period of nitrogen accumulation by all crops was before flowering or anthesis.

As shown in Fig. 1, in all furrow fertigation (FF) and farmers' conventional fertilization (FCF) treatments, the highest and the lowest aboveground nitrogen were obtained in
Table 4 Mean of maize aboveground nitrogen content in furrow fertigation treatments (FF) and farmers' conventional fertilization treatment (FCF) at different maize growth stages

\begin{tabular}{|c|c|c|c|c|c|c|}
\hline \multirow[t]{2}{*}{ Treatment } & \multicolumn{2}{|l|}{ Level (\%) } & \multicolumn{4}{|l|}{$\mathrm{N}$ content (\%) } \\
\hline & $\mathrm{N}$-fertilizer & Water & Seven-leaf & Shooting & Flowering & Harvesting \\
\hline \multirow[t]{16}{*}{ FF } & \multirow[t]{4}{*}{ N1 } & W1 & $2.84 \pm 0.23^{b c}$ & $2.18 \pm 0.56^{f}$ & $1.96 \pm 0.11^{\mathrm{g}}$ & $1.04 \pm 0.24^{k}$ \\
\hline & & W2 & $2.9 \pm 0.43^{b}$ & $1.8 \pm 0.43^{g}$ & $2.27 \pm 0.32^{\mathrm{ef}}$ & $1.7 \pm 0.36^{\mathrm{h}}$ \\
\hline & & W3 & $2.67 \pm 0.34^{c}$ & $1.87 \pm 0.33^{g}$ & $2.23 \pm 0.18^{\mathrm{ef}}$ & $1.77 \pm 0.42^{h}$ \\
\hline & & W4 & $2.73 \pm 0.12^{b c}$ & $1.7 \pm 0.26^{\mathrm{h}}$ & $1.78 \pm 0.12^{g}$ & $1.14 \pm 0.39^{\mathrm{jk}}$ \\
\hline & \multirow[t]{4}{*}{ N2 } & W1 & $2.54 \pm 0.36^{d}$ & $1.21 \pm 0.19^{j}$ & $1.74 \pm 0.14^{\mathrm{g}}$ & $1.19 \pm 0.37^{\mathrm{j}}$ \\
\hline & & W2 & $2.34 \pm 0.24^{\mathrm{e}}$ & $1.87 \pm 0.61^{g}$ & $2.04 \pm .19^{f}$ & $1.72 \pm 0.28^{h}$ \\
\hline & & W3 & $2.7 \pm 0.17^{c}$ & $1.50 \pm 0.48^{i}$ & $2.11 \pm .032^{f}$ & $1.79 \pm 0.43^{h}$ \\
\hline & & W4 & $2.87 \pm 0.34^{b c}$ & $1.22 \pm 0.52^{\mathrm{j}}$ & $1.48 \pm 0.37^{j}$ & $0.68 \pm 0.19^{1}$ \\
\hline & \multirow[t]{4}{*}{ N3 } & W1 & $2.47 \pm 0.22^{\mathrm{de}}$ & $1.14 \pm 0.43^{k}$ & $1.57 \pm 0.14^{\mathrm{hi}}$ & $0.86 \pm 0.23^{\mathrm{kl}}$ \\
\hline & & W2 & $2.69 \pm 0.31^{c}$ & $1.5 \pm 0.52^{i}$ & $1.56 \pm 0.18^{h i}$ & $0.94 \pm 0.17^{k}$ \\
\hline & & W3 & $2.6 \pm 0.30^{c d}$ & $1.14 \pm 0.23^{k}$ & $1.61 \pm 0.29^{g h}$ & $0.98 \pm 0.27^{k}$ \\
\hline & & W4 & $2.46 \pm 0.41^{\text {de }}$ & $1.5 \pm 0.33^{i}$ & $1.46 \pm 0.29^{i}$ & $0.74 \pm 0.13^{1}$ \\
\hline & \multirow[t]{4}{*}{ N4 } & W1 & $0.61 \pm 0.18^{1}$ & $0.63 \pm 0.44^{\prime}$ & $0.67 \pm 0.30^{1}$ & $0.58 \pm 0.26^{1}$ \\
\hline & & W2 & $0.59 \pm 0.13^{1}$ & $0.51 \pm 0.15^{1}$ & $0.56 \pm 0.26^{1}$ & $0.57 \pm 0.17^{1}$ \\
\hline & & W3 & $0.66 \pm 0.21^{1}$ & $0.54 \pm 0.19^{1}$ & $0.58 \pm 0.37^{1}$ & $0.58 \pm 0.21^{1}$ \\
\hline & & W4 & $0.64 \pm 0.11^{1}$ & $0.58 \pm 0.21^{1}$ & $0.69 \pm 0.25^{1}$ & $0.59 \pm 0.26^{1}$ \\
\hline FCF & N1 & W1 & $3.11 \pm 0.45^{\mathrm{a}}$ & $2.11 \pm 0.37^{f}$ & $1.71 \pm 0.31^{\mathrm{h}}$ & $1.45 \pm 0.35^{\mathrm{i}}$ \\
\hline
\end{tabular}

Results are means \pm standard deviations $(n=4)$. Values with the different lower-case letters are significantly different at $P \leq 0.05$ according to the LSD test 

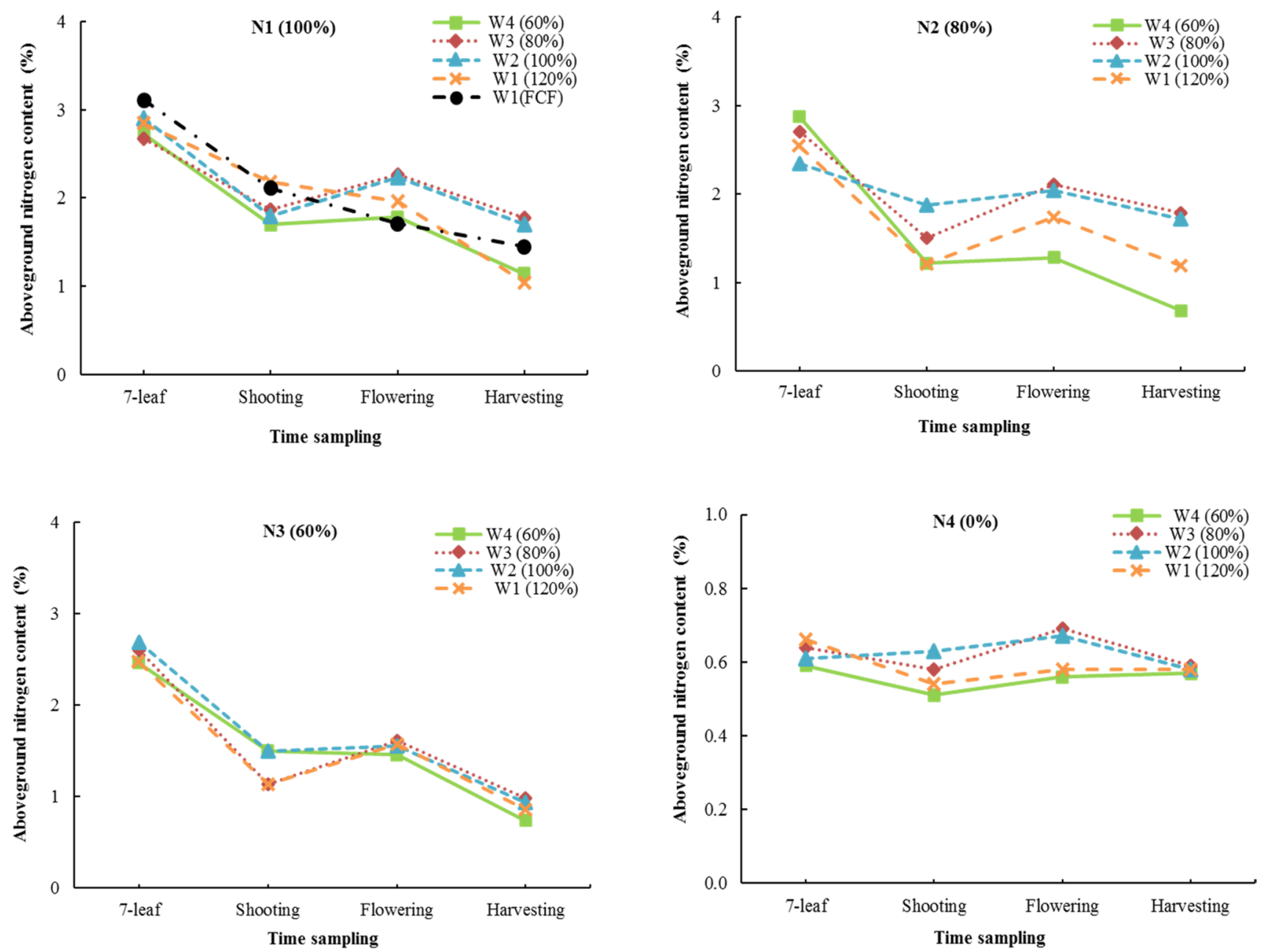

Fig. 1 Aboveground nitrogen content in four growth stages of maize (7-leaf, shooting, flowering, harvesting) at different levels of N-fertilizer (N1-4) and irrigation water (W1-4), and farmers' conventional fertilization treatment (FCF). Results are means of four replications

the seven-leaf and harvesting stages, respectively. Except for FCF treatment, there was an increase in nitrogen content at the flowering stage after reduction in the shooting stage in all FF treatments. Besides, FCF treatment showed a downward trend in the plant nitrogen content. Application of $50 \%$ of required fertilizer before planting could be considered one of the main contributing factors to a decrease in the plant nitrogen content in FCF treatment [36]. Therefore, nitrogen management strategies regarding the timing and method of $\mathrm{N}$-fertilizer application would be needed to minimize nitrate losses and maximize plant productivity [32]. A study by Zhou et al. [37] found that the split application of $300 \mathrm{~kg} \mathrm{~N} \mathrm{ha}^{-1}$ (20\% N before planting, $25 \% \mathrm{~N}$ at the six-leaf stage, $35 \% \mathrm{~N}$ at the twelve -leaf stage, and $20 \% \mathrm{~N}$ at the silking stage) gave the highest maize nitrate content compared with two split applications of $300 \mathrm{~kg} \mathrm{~N} \mathrm{ha}^{-1}(60 \% \mathrm{~N}$ before planting and $40 \% \mathrm{~N}$ at the six-leaf stage), which then resulted in a significant increase in plant grain yield.

\subsection{Nitrate losses through deep leeching}

Results of nitrate mass balance at $80 \mathrm{~cm}$ soil layer (below the plant root zone) indicated that the amounts of nitrate deep leaching increased with increasing irrigation water levels at each growth stage of the plant (Fig. 2). At this depth, nitrate deep leaching was only observed in furrow fertigation treatments (FF), which consisted of $100 \%$ (N1) level of required $\mathrm{N}$-fertilizer and 120 (W1), 100 (W2), and $80 \%$ (W3) levels of required irrigation water, and farmers' conventional fertilization treatment (FCF). In contrast, nitrate deep leaching was not observed in other $\mathrm{N}$-fertilizer levels $(0,60$, and $80 \%)$ and $60 \%$ level of irrigation water. The general changes in the amount of nitrate deep leaching during the plant growth stages were similar in all FF and FCF treatments. Unlike W1N1, W2N1 treatments, in which nitrate deep leaching gradually decreased, nitrate leaching in W3N1 treatment decreased sharply, which may be explained by a greater influence of $60 \%$ level of 
Fig. 2 The amounts of nitrate deep leaching at $80 \mathrm{~cm}$ soil layer in four growth stages of maize (7-leaf, shooting, flowering, harvesting) at $100 \%$ level of required $\mathrm{N}$-fertilizer (N1) and 80 (W3), 100 (W2), and $120 \%$ (W1) levels of required irrigation water, and farmers' conventional fertilization treatment (FCF). Results are means of four replications

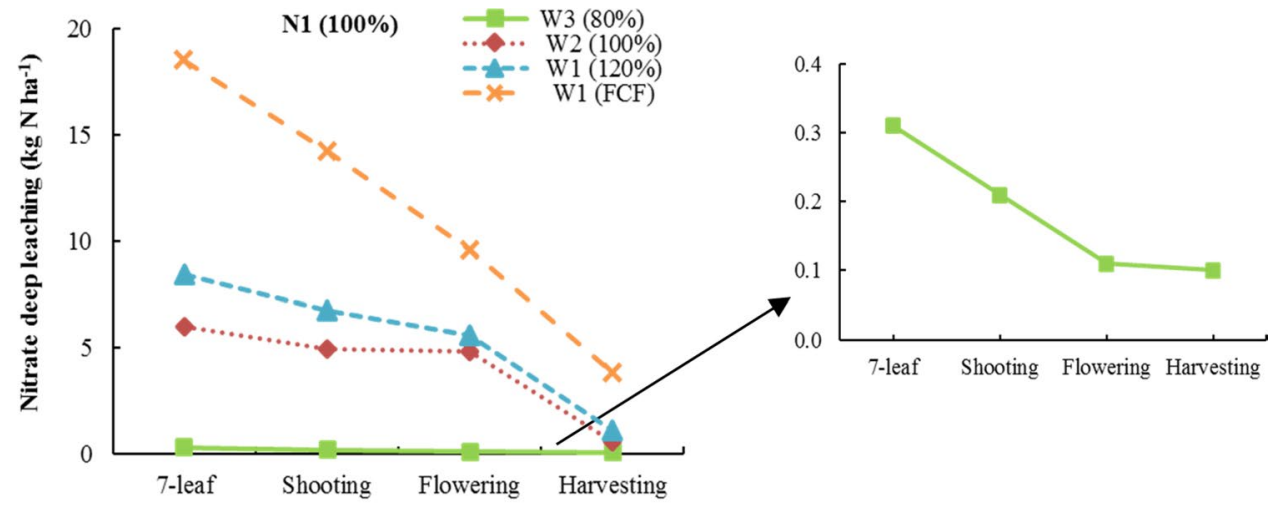

Time sampling required irrigation water on the efficiency of split $\mathrm{N}$ application during the maize growth stages than 100 and $80 \%$ level of required irrigation water. Additionally, in FCF treatment, despite a sharp decrease in nitrate deep leaching with increased plant growth, the amount of nitrate leaching was higher than FF treatments, which is most likely attributed to the addition of $50 \%$ level of required $\mathrm{N}$-fertilizer before planting.

As shown in Table 5, a reduction of irrigation water levels from 120 to $100 \%$ and $80 \%$ gave a significant reduction in nitrate deep leaching at four growth stages. Besides, a cumulative study of nitrate deep leaching indicated that W1N1 treatment had the highest deep leaching with $11.9 \%$, followed by W2N1 and W3N1. With the decreasing level of irrigation water (W4N1), the amount of nitrate leaching reached to $0 \%$. As a result of these nitrate deep leaching at $\mathrm{W} 1 \mathrm{~N} 1$ and $\mathrm{W} 2 \mathrm{~N} 1$ treatments, $\mathrm{N}$-fertilizer and irrigation water utilization need to be effectively managed. Therefore, $\mathrm{N}$ application in a most split and water irrigation usage at low levels might be the best effective way of water and $\mathrm{N}$-fertilizer management with respect to high yield. Additionally, the amount of nitrate deep leaching in FCF treatment was about $25 \%$. Application of more N-fertilizer and irrigation water, where $50 \%$ of required fertilizer was applied before planting, resulted in a twofold increase in nitrate deep leaching in FCF treatment compared to W1N1treatment. While, at this stage (before planting), soil organic matter can partly provide the initial nitrogen requirements of the plant [38]. Tafteh and sepaskhah [5] concluded that the amount of $\mathrm{N}$-fertilizer should be decreased in proportion to the amount of available soil water for plant uptake under deficit irrigation to prevent nitrogen losses. Gheysari et al. [11] investigated the nitrogen leaching out of the $60 \mathrm{~cm}$ soil layer under sprinkler fertigation management and found that management significantly reduces nitrate leaching. They reported that nitrate losses are low in deficit irrigated treatment and the maximum nitrate leaching was obtained in the fertigation treatment involving $8.43 \mathrm{~kg} \mathrm{~N} \mathrm{ha}^{-1}$ and over-irrigation.

\subsection{Nitrate loss through surface runoff}

Comparison of nitrate runoff loss results between FF treatments and FCF treatment revealed that FCF treatment had the highest amount of nitrate runoff loss (Fig. 3). In FF treatments, with the exception of nitrate runoff loss results for N4 treatments, which showed no losses, nitrate runoff loss increased with increasing irrigation water levels at different levels of required $\mathrm{N}$-fertilizer. Overall, the highest amount of nitrate runoff losses was observed in W1N1 and

Table 5 Mean of nitrate deep leaching in furrow fertigation treatments (FF) and farmers' conventional fertilization treatment (FCF) at different growth stages of maize

\begin{tabular}{|c|c|c|c|c|c|c|c|}
\hline \multirow[t]{2}{*}{ Treatment } & \multicolumn{2}{|l|}{ Level (\%) } & \multicolumn{4}{|c|}{$\mathrm{NO}_{3}$-soil $\left(\mathrm{kg} \mathrm{N} \mathrm{ha}^{-1}\right)$} & \multirow{2}{*}{$\begin{array}{l}\text { Cumulative } \\
\text { nitrate losses } \\
(\%)\end{array}$} \\
\hline & $\mathrm{N}$-fertilizer & Water & Seven-leaf & Shooting & Flowering & Harvesting & \\
\hline \multirow[t]{3}{*}{ FF } & N1 & W1 & $8.43 \pm 1.72^{c}$ & $6.75 \pm 0.93^{d}$ & $5.59 \pm 1.47^{\text {de }}$ & $1.12 \pm 0.21^{\mathrm{g}}$ & $11.9 \pm 1.95^{\mathrm{b}}$ \\
\hline & & W2 & $5.97 \pm 1.23^{\mathrm{de}}$ & $4.95 \pm 1.52^{\mathrm{e}}$ & $4.86 \pm 1.12^{\mathrm{e}}$ & $0.59 \pm 0.14^{\mathrm{hi}}$ & $8.9 \pm 1.38^{c}$ \\
\hline & & W3 & $0.31 \pm 0.12^{\mathrm{ij}}$ & $0.21 \pm 0.09^{j}$ & $0.11 \pm 0.01^{k}$ & $0.10 \pm 0.02^{k}$ & $0.4 \pm 0.08^{d}$ \\
\hline FCF & N1 & W1 & $18.47 \pm 1.15^{\mathrm{a}}$ & $14.26 \pm 0.53^{b}$ & $9.62 \pm 1.63^{c}$ & $3.83 \pm 0.62^{f}$ & $25.1 \pm 3.87^{\mathrm{a}}$ \\
\hline
\end{tabular}

Results are means \pm standard deviations $(n=4)$. Values with the different lower-case letters are significantly different at $P \leq 0.05$ according to the LSD test 


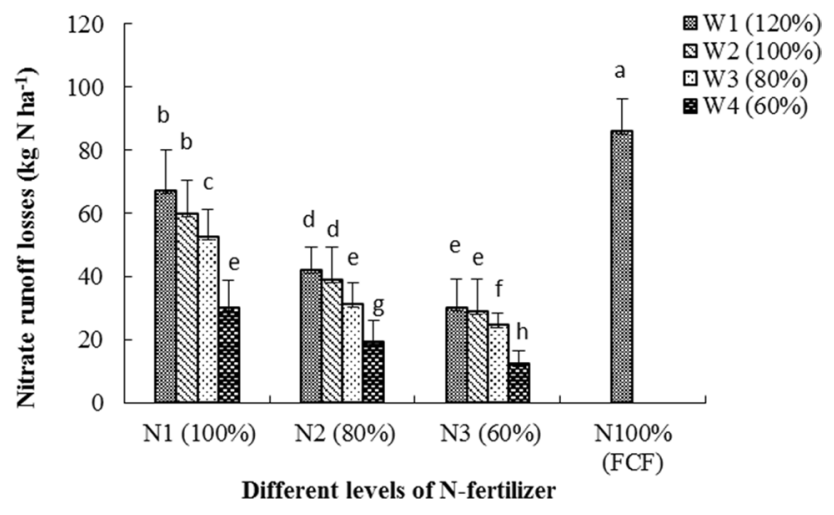

Fig. 3 Comparison of nitrate runoff losses in furrow fertigation treatments (FF) and farmers' conventional fertilization treatment (FCF). Values with the different lower-case letters are significantly different at $P \leq 0.05$ according to the LSD test. Error bars represent standard deviations $(n=4)$

W2N1 treatments. The optimal level of $\mathrm{N}$-fertilizer application is dependent on the depth of irrigation water. The impact of exposure to excess irrigation water and $\mathrm{N}$-fertilizer can be very significant not only in reducing plant yield but also in deteriorating surface water quality [39]. Abbasi et al. [40] investigated the effects of furrow fertigation management on nitrate losses through surface runoff in a cornfield and stated that the nitrate losses have ranged between 5.7 and $42.0 \%$. They reported that the highest value of nitrogen losses was obtained at $100 \%$ level of required $\mathrm{N}$-fertilizer combined with 120,100 , and $80 \%$ levels of required irrigation water, respectively. Sabillón and Merkley [41] also reported with increasing surface runoff water losses from 20 up to $67 \%$ nitrate losses increased from 3 up to $55 \%$.

\subsection{Maize yield and vegetative characteristics}

Comparison of maize yield and vegetative characteristics in different levels of $\mathrm{N}$-fertilizer and irrigation water showed that the means value of yield and vegetative characteristics increased with the increasing rate of $\mathrm{N}$-fertilizer $(\mathrm{N} 1>\mathrm{N} 2>\mathrm{N} 3>\mathrm{N} 4)$, as well as decreasing the amount of irrigation water from level of $120 \%$ (W1) to level of $100 \%$ (W2) and 80\% (W3) (Table 6). Generally, W2N1 treatment had the highest grain yield, aboveground biomass, plant height, number of leaves, stem diameter in comparison with other treatments. However, there were no significant differences between W2N1, W3N1, W2N2, and W3N2 treatments on yield and vegetative characteristics. Moreover, FCF treatment had significantly lower grain yield and vegetative growth characteristics compared with W2N1, W3N1,

Table 6 Mean of maize grain yield and vegetative growth characteristics grown in furrow fertigation treatments (FF) and farmers' conventional fertilization treatment (FCF)

\begin{tabular}{|c|c|c|c|c|c|c|c|}
\hline \multirow[t]{2}{*}{ Treatment } & \multicolumn{2}{|l|}{ Level (\%) } & \multicolumn{5}{|c|}{ Yield and vegetative growth characteristics } \\
\hline & $\mathrm{N}$-fertilizer & Water & Grain yield (ton ha ${ }^{-1}$ ) & $\begin{array}{l}\text { Aboveground } \\
\text { biomass (ton } \\
\mathrm{ha}^{-1} \text { ) }\end{array}$ & Plant height $(\mathrm{cm})$ & Number of leaves & Stem diameter $(\mathrm{cm})$ \\
\hline \multirow[t]{16}{*}{ FF } & \multirow[t]{4}{*}{ N1 } & W1 & $8.47 \pm 0.30^{b}$ & $17.52 \pm 0.43^{\mathrm{cd}}$ & $211.4 \pm 1.22^{c}$ & $11.31 \pm 0.74^{c}$ & $2.06 \pm 0.12^{c}$ \\
\hline & & W2 & $12.93 \pm 0.52^{\mathrm{a}}$ & $21.88 \pm 0.59^{\mathrm{a}}$ & $231.4 \pm 2.34^{\mathrm{a}}$ & $13.59 \pm 0.65^{\mathrm{a}}$ & $2.43 \pm 0.16^{\mathrm{a}}$ \\
\hline & & W3 & $12.43 \pm 0.83^{\mathrm{a}}$ & $20.13 \pm 0.61^{\mathrm{ab}}$ & $225.5 \pm 2.12^{\mathrm{ab}}$ & $12.47 \pm 1.01^{\mathrm{ab}}$ & $2.31 \pm 0.22^{\mathrm{ab}}$ \\
\hline & & W4 & $7.43 \pm 0.35^{c}$ & $16.91 \pm 0.39^{\mathrm{de}}$ & $202.7 \pm 3.43^{c d}$ & $10.54 \pm 0.87^{d}$ & $1.99 \pm 0.34^{\mathrm{cd}}$ \\
\hline & \multirow[t]{4}{*}{$\mathrm{N} 2$} & W1 & $6.27 \pm 0.57^{\mathrm{de}}$ & $15.25 \pm 0.33^{f}$ & $200.06 \pm 1.65^{\mathrm{cd}}$ & $11.61 \pm 0.65^{c}$ & $1.95 \pm 0.65^{\mathrm{cd}}$ \\
\hline & & W2 & $12.61 \pm 0.96^{\mathrm{a}}$ & $20.26 \pm 0.62^{\mathrm{ab}}$ & $229.3 \pm 1.01^{\mathrm{a}}$ & $12.78 \pm 0.98^{\mathrm{ab}}$ & $2.28 \pm 0.76^{\mathrm{ab}}$ \\
\hline & & W3 & $12.27 \pm 0.54^{\mathrm{a}}$ & $19.95 \pm 0.57^{\mathrm{ab}}$ & $222.5 \pm 2.12^{\mathrm{ab}}$ & $12.42 \pm 0.43^{\mathrm{ab}}$ & $2.26 \pm 0.32^{\mathrm{ab}}$ \\
\hline & & W4 & $6.58 \pm 0.39^{d}$ & $17.14 \pm 0.37^{c d}$ & $201.5 \pm 1.78^{\mathrm{cd}}$ & $10.11 \pm 0.65^{\mathrm{de}}$ & $2.02 \pm 0.43^{c}$ \\
\hline & \multirow[t]{4}{*}{ N3 } & W1 & $7.59 \pm 0.27^{c}$ & $16.01 \pm 0.43^{\mathrm{ef}}$ & $209.15 \pm 3.76^{c}$ & $10.12 \pm 0.76^{\mathrm{de}}$ & $1.90 \pm 0.54^{\mathrm{de}}$ \\
\hline & & W2 & $9.27 \pm 0.57^{b}$ & $17.21 \pm 0.48^{\mathrm{cd}}$ & $199.5 \pm 2.34^{d}$ & $11.23 \pm .38^{c}$ & $2.11 \pm 0.65^{c}$ \\
\hline & & W3 & $9.08 \pm 0.42^{b}$ & $15.43 \pm 0.46^{\mathrm{fg}}$ & $192.6 \pm 1.24^{\mathrm{de}}$ & $10.14 \pm 0.57^{\mathrm{de}}$ & $1.86 \pm 0.76^{\mathrm{de}}$ \\
\hline & & W4 & $5.32 \pm 0.50^{f}$ & $14.02 \pm 0.43^{g h}$ & $183.9 \pm 2.76^{\mathrm{ef}}$ & $9.17 \pm 0.66^{f}$ & $1.80 \pm 0.87^{\mathrm{ef}}$ \\
\hline & \multirow[t]{4}{*}{ N4 } & W1 & $3.27 \pm 0.45^{\mathrm{g}}$ & $14.82 \pm 0.31^{g}$ & $178.6 \pm 3.56^{\mathrm{fg}}$ & $9.81 \pm 1.12^{\mathrm{fg}}$ & $1.70 \pm 0.67^{f}$ \\
\hline & & W2 & $5.43 \pm 0.55^{\mathrm{ef}}$ & $14.57 \pm 0.32^{g h}$ & $176.3 \pm 2.54^{\mathrm{g}}$ & $9.73 \pm 0.94^{f g}$ & $1.77 \pm 0.75^{\mathrm{ef}}$ \\
\hline & & W3 & $3.36 \pm 0.64^{9}$ & $12.03 \pm 0.39^{\mathrm{ij}}$ & $180.4 \pm 1.43^{e f}$ & $9.10 \pm 0.77^{9}$ & $1.60 \pm 0.34^{\mathrm{g}}$ \\
\hline & & W4 & $2.15 \pm 0.39^{h}$ & $11.29 \pm 0.28 j$ & $165.4 \pm 3.21^{\mathrm{h}}$ & $8.74 \pm 0.43^{h}$ & $1.56 \pm 0.26^{\mathrm{h}}$ \\
\hline FCF & N1 & W1 & $7.32 \pm 0.46^{c}$ & $15.06 \pm 0.47^{\mathrm{fg}}$ & $203.6 \pm 3.32^{\mathrm{cd}}$ & $10.82 \pm 0.54^{d}$ & $2.18 \pm 0.52^{c}$ \\
\hline
\end{tabular}

Results are means \pm standard deviations $(n=4)$. Values with the different lower-case letters within each column are significantly different at $P \leq 0.05$ according to the LSD test 
W2N2, and W3N2 treatments. This result also coincides with a decrease in nitrate losses and an increase in plant nitrate content, which has been shown to significantly influence maize yield and vegetative characteristics grown in FF treatments. A study by Ning et al. [42] found that three splits of $\mathrm{N}$ at a total rate of $180 \mathrm{~N} \mathrm{~kg} \mathrm{ha}^{-1}$ applied through drip-fertigated system (30\% at the three-leaf stage, $40 \%$ at the sixleaf stage, $20 \%$ at the twelve-leaf stage, and $10 \%$ at the milk stage) were a superior strategy for vertical enhancement of maize yield compared to split applications of $90 \mathrm{~N} \mathrm{~kg} \mathrm{ha}^{-1}$ in a drip-fertigated system. Ogunboye et al. [43] revealed that three split applications of $120 \mathrm{~kg} \mathrm{~N} \mathrm{ha}^{-1}$ increased maize yield and growth parameters by $37.1 \%$ compared with $120 \mathrm{~kg} \mathrm{~N} \mathrm{ha}^{-1}$ applied at planting.

\section{Conclusion}

The results showed that unlike FCF treatment, in all FF treatments, after decreasing plant nitrogen content in the shooting stage, the plant nitrogen increased at the flowering stage, which then resulted in a significant increase in plant yield and vegetative growth characteristics. Comparisons of the amount of nitrate deep leaching and nitrate runoff losses between FF and FCF treatments revealed a significant increase in nitrate losses in FCF treatment compared to FF treatments. Generally, these results showed that the application of moderate irrigation water and split $\mathrm{N}$ by furrow fertigation would be a useful strategy for achieving high yield in maize and reducing nitrate losses even for high $\mathrm{N}$ rates.

Acknowledgements The authors appreciate the University of Tehran, Karaj, Iran and Agricultural Engineering Research Institute, Karaj, Iran, for the financial and technical supports of this study.

Funding This work was financially supported by the University of Tehran, Karaj, Iran.

Availability of data and material The datasets used and/or analysed during the current study are available from the corresponding author on reasonable request.

\section{Compliance with ethical standards}

Conflict of interest The authors declare that they have no conflict of interest.

Code availability Not applicable.

Open Access This article is licensed under a Creative Commons Attribution 4.0 International License, which permits use, sharing, adaptation, distribution and reproduction in any medium or format, as long as you give appropriate credit to the original author(s) and the source, provide a link to the Creative Commons licence, and indicate if changes were made. The images or other third party material in this article are included in the article's Creative Commons licence, unless indicated otherwise in a credit line to the material. If material is not included in the article's Creative Commons licence and your intended use is not permitted by statutory regulation or exceeds the permitted use, you will need to obtain permission directly from the copyright holder. To view a copy of this licence, visit http://creativecommons .org/licenses/by/4.0/.

\section{References}

1. Zand-Parsa S, Sepaskhah A, Ronaghi A (2006) Development and evaluation of integrated water and nitrogen model for maize. Agric Water Manag 81(3):227-256

2. Ercoli L, Lulli L, Mariotti M, Masoni A, Arduini I (2008) Postanthesis dry matter and nitrogen dynamics in durum wheat as affected by nitrogen supply and soil water availability. Eur J Agron 28(2):138-147

3. Wang Y, Thorup-Kristensen K, Jensen LS, Magid J (2016) Vigorous root growth is a better indicator of early nutrient uptake than root hair traits in spring wheat grown under low fertility. Front Plant Sci 7:865

4. Sharma L, Bali S (2017) A review of methods to improve nitrogen use efficiency in agriculture. Sustainability 10(1):51

5. Tafteh A, Sepaskhah AR (2012) Yield and nitrogen leaching in rapeseed field under different nitrogen rates and water saving irrigation. Agr Water Manag 112:55-62

6. Jalali M (2005) Nitrates leaching from agricultural land in Hamadan, western Iran. Agric Ecosyst Environ 110(3):210-218

7. Sui J, Wang J, Gong S, Xu D, Zhang Y (2015) Effect of nitrogen and irrigation application on water movement and nitrogen transport for a wheat crop under drip irrigation in the North China Plain. Water 7(11):6651-6672

8. Salo T (2008) Effects of band placement and nitrogen rate on dry matter accumulation, yield and nitrogen uptake of cabbage, carrot and onion. Agric Food Sci 8(2):157-232

9. Contreras Jl, Eymar E, Lopez JG, Lao MT, Segura ML (2013) Influences of nitrogen and potassium fertigation on nutrient uptake, production, and quality of pepper irrigated with disinfected urban wastewater. Commun Soil Sci Plan 44(1-4):767-775

10. Rasool G, Xiangping G, Zhenchang W, Sheng C, Alhaj Hamoud Y, Qiser J (2019) Response of fertigation under buried straw layer on growth, yield, and water-fertilizer productivity of Chinese cabbage under greenhouse conditions. Commun Soil Sci Plan 50(8):1030-1043

11. Gheysari M, Mirlatifi SM, Homaee M, Asadi ME, Hoogenboom $G$ (2009) Nitrate leaching in a silage maize field under different irrigation and nitrogen fertilizer rates. Agric Water Manag 96(6):946-954

12. Smika D, Heermann D, Duke $H$, Bathchelder A (1977) Nitrate-N percolation through irrigated sandy soil as affected by water management. Agron J 69(4):623-626

13. Antille DL (2018) Evaluation of fertigation applied to furrow and overhead irrigated cotton grown in a Black Vertosol in Southern Queensland. Aust Appl Eng Agric 34(1):197-211

14. Hou Z, Li P, Li B, Gong J, Wang Y (2007) Effects of fertigation scheme on $\mathrm{N}$ uptake and $\mathrm{N}$ use efficiency in cotton. Plant Soil 290(1-2):115-126

15. Zerihun D, Sanchez C, Farrell-Poe K, Adamsen F, Hunsaker D (2003) Performance indices for surface N fertigation. J Irrig Drain Eng 129(3):173-183

16. Burguete J, Zapata N, García-Navarro P, Maïkaka M, Playán E, Murillo J (2009) Fertigation in furrows and level furrow systems. I: model description and numerical tests. J Irrig Drain Eng 135(4):401-412 
17. Šimůnek J, Bristow KL, Helalia SA, Siyal AA (2016) The effect of different fertigation strategies and furrow surface treatments on plant water and nitrogen use. Irrig Sci 34(1):53-69

18. Gee GW, Bauder JW (1986) Particle size analysis. In: Klute A (ed) Methods of soil analysis, American Society of Agronomy. Soil Science Society of America, Madison, pp 383-409

19. Thomas GW (1996) Soil pH and soil acidity. In: Sparks DL (ed) Methods of soil analysis part 3 chemical methods. Soil Science Society of America, Madison, pp 475-490

20. Rhoades JD (1996) Salinity: electrical conductivity and total dissolved solids. In: Sparks DL (ed) Methods of soil analysis part 3 chemical methods. Soil Science Society of America, Madison, pp 417-435

21. Blake G (1965) Bulk density. In: Black CA (ed) Methods of soil analysis part 1 agronomy monographs. Soil Science Society of America Book, Madison, pp 374-390

22. Nelson DW, Sommers LE (1996) Total carbon, organic carbon, and organic matter. In: Sparks DL (ed) Methods of soil analysis part 3 chemical methods. Soil Science Society of America, Madison, pp 961-1010

23. Abbasi F, Feyen J, Roth RL, Sheedy M, Van Genuchten MT (2003) Water flow and solute transport in furrow-irrigated fields. Irrig Sci 22(2):57-65

24. Abbasi F, Rezaee HT, Jolaini M, Alizadeh HA (2012) Evaluation of fertigation in different soils and furrow irrigation regimes. Irrig Drain 61(4):533-541

25. Ertek A (2011) Importance of pan evaporation for irrigation scheduling and proper use of crop-pan coefficient (Kcp), crop coefficient $(\mathrm{Kc})$ and pan coefficient $(\mathrm{Kp})$. Afric J Agric Res 6(32):6706-6718

26. Zou X, Niu W, Liu J, Li Y, Liang B, Guo L, Guan Y (2017) Effects of residual mulch film on the growth and fruit quality of tomato (Lycopersicon esculentum Mill.). Water Air Soil Pollut 228(2):71

27. Begcy K, Dresselhaus T (2017) Tracking maize pollen development by the Leaf Collar Method. Plant Reprod 30(4):171-178

28. Bremner I, Mulvaney C (1982) Nitrogen-total. In: Page A, Miller $R$, Keeney $D$ (eds) Methods of soil analysis part 2 chemical and microbiological properties. American Society of Agronomy, Madison, pp 595-624

29. Jenkins D, Medsker LL (1964) Brucine method for the determination of nitrate in ocean, estuarine, and fresh waters. Anal Chem 36(3):610-612

30. Wang $X$, Xing $Y$ (2017) Effects of irrigation and nitrogen on maize growth and yield components. Global Changes and Natural Disaster Management: Geo-information Technologies, pp 63-74.

31. Hammad HM, Farhad W, Abbas F, Fahad S, Saeed S, Nasim W, Bakhat HF (2017) Maize plant nitrogen uptake dynamics at limited irrigation water and nitrogen. Environ Sci Pollut Res 24(3):2549-2557

32. Barakat M, Cheviron B, Angulo-Jaramillo R (2016) Influence of the irrigation technique and strategies on the nitrogen cycle and budget: a review. Agric Water Manag 178:225-238
33. Zhang Y, Wang $H$, Lei Q, Luo J, Lindsey S, Zhang J, Zhai L, Wu Sh, Zhang J, Liu X, Ren T, Liu H (2018) Optimizing the nitrogen application rate for maize and wheat based on yield and environment on the Northern China Plain. Sci Total Environ 618:1173-1183

34. Girma K, Holtz S, Tubaña B, Solie J, Raun W (2010) Nitrogen accumulation in shoots as a function of growth stage of corn and winter wheat. J Plant Nutr 34(2):165-182

35. Hocking P, Stapper $M$ (2001) Effects of sowing time and nitrogen fertiliser on canola and wheat, and nitrogen fertiliser on Indian mustard I Dry matter production, grain yield, and yield components. Aust J Agric Res 52(6):623-634

36. Liu Z, Gao F, Liu Y, Yang J, Zhen X, Li X, Li Y, Zhao J, Li J, Qian B, Yang D, Li X (2019) Timing and splitting of nitrogen fertilizer supply to increase crop yield and efficiency of nitrogen utilization in a wheat-peanut relay intercropping system in China. Crop J 7(1):101-112

37. Zhou B, Sun X, Wang D, Ding Z, Li C, Ma W, Zhao M (2019) Integrated agronomic practice increases maize grain yield and nitrogen use efficiency under various soil fertility conditions. Crop J 7(4):527-538

38. Xiang $Y$, Zou $H$, Zhang F, Qiang $S$, Wu Y, Yan S, Wang H, Lifeng Wu, Fan J, Wang $X$ (2018) Effect of irrigation level and irrigation frequency on the growth of mini Chinese cabbage and residual soil nitrate nitrogen. Sustainability 11(1):1-20

39. Chojnacka K, Witek-Krowiak A, Moustakas K, Skrzypczak D, Mikula K, Loizidou M (2020) A transition from conventional irrigation to fertigation with reclaimed wastewater: prospects and challenges. Renew Sust Energ Rev 130:109959

40. Abbasi $Y$, Abbasi F, Liaghat A, Alizadeh HA (2011) Evaluation of furrow fertigation and model validation on maize field. Irrig Drain Syst 25(4):279-291

41. Sabillón G, Merkley G (2004) Fertigation guidelines for furrow irrigation. Span J Agric Res 2(4):576-587

42. Ning D, Qin A, Duan A, Xiao J, Zhang J, Liu Z, Liu Z, Liu Z (2019) Deficit irrigation combined with reduced $\mathrm{N}$-fertilizer rate can mitigate the high nitrous oxide emissions from Chinese dripfertigated maize field. Glob Ecol Conserv 20:e00803

43. Ogunboye Ol, Adekiya AO, Ewulo SB, Olayanju A (2020) Effects of split application of urea fertilizer on soil chemical properties, maize performance and profitability in Southwest Nigeria. Open Agric J 14(1):36-42

Publisher's Note Springer Nature remains neutral with regard to jurisdictional claims in published maps and institutional affiliations. 